\title{
Immunological and virological characterization of HIV-1 viremia controllers in the North Region of Brazil
}

Samara Tatielle M. Gomes ${ }^{\dagger}$, Érica R. Gomes ${ }^{\dagger}$, Mike B. dos Santos, Sandra S. Lima, Maria Alice F. Queiroz, Luiz Fernando A. Machado, Izaura M. V. Cayres-Vallinoto, Antonio Carlos R. Vallinoto, Marluísa de O. Guimarães Ishak and Ricardo Ishak

\begin{abstract}
Background: A rare phenotype of clinical non-progressors to AIDS is not well understood and the new protocol for universal treatment, may block the understanding of viral control thus it is crucial to define this controversial group.

Methods: A cohort of 30 persons followed a criteria for viremia control groups $1(\mathrm{VC} 1 ; n=2)$ and $2(\mathrm{VC} 2 ; n=7)$ and non-viral controllers (NC; $n=21$ ) including number of years of diagnosis, $\mathrm{LTCD}^{+}, \mathrm{LTCD}^{+}$counts, plasma viral load and the absence of ART; 241 uninfected control persons were matched to age and sex. Infected persons were regularly examined and submitted to two or three annual laboratory measurements. Polymorphisms and allele frequencies of CCR5 $\Delta 32$ and SDF1-3'A were detected in the genomic DNA. Plasma levels of cytokines (IL-2, IL-4, IL-5, IL-9, IL-10, IL-13, IL-17 and IFN-y) were measured.

Results: The group investigated is originated from a miscigenetic population and demographic and social characteristics were not significantly relevant. LTCD4 $4^{+}$median values were higher among VC than NC, but significantly lower than uninfected controls. Evolution of $\mathrm{LTCD}^{+}$and $\mathrm{LTCD}^{+}$counts, showed a slight increase of $\mathrm{LTCD} 4^{+}$among VC, but a significant decrease in the NC. The percentage of annual change in $\mathrm{LTCD}^{+}$was also significantly different between the groups. $\mathrm{LTCD}^{+} / \mathrm{LTCD} 8^{+}$ratio was inverted but not significant among the $\mathrm{VC}$, thus the ratio may be a useful biomarker for the VC. A clear signature indicated a change from Th1 to Th2 cytokine profiles from VC to NC, respectively.

Conclusions: The knowledge of viral controllers characteristics in different population groups is important to define a strict universal definition for the sake of learning about the pathogenesis of HIV-1. Data on LTCD4 ${ }^{+}$seems to be stable and repetitive from published data, but the $\mathrm{LTCD}^{+}$response and the significance of $\mathrm{LTCD} 4^{+} / \mathrm{LTCD} 8^{+}$ratio values are in need to further exploration as biomarkers. The change from Th1 to Th2 cytokine profile may help to design and adjust specific treatment protocols for the group.
\end{abstract}

Keywords: HIV-1, Viral controllers, Elite controllers, Cytokines, CCR5, SDF1

\section{Background}

The usual period of slow, but continuous viral replication of HIV-1, T CD4 ${ }^{+}$lymphocyte $\left(\mathrm{LTCD}_{4}^{+}\right)$decline and the appearance of AIDS followed by death, was the natural history accompanying HIV-1 infecting humans $[1,2]$. The use of different protocols which should be strictly followed to treat the viral infection (antiretroviral therapy, ART),

\footnotetext{
* Correspondence: rishak@ufpa.br

${ }^{\dagger}$ Equal contributors

Federal University of Para, Institute of Biological Sciences, Virus Laboratory,

Campus Belem, Belem, Para 66000-000, Brazil
}

made it possible to interfere in the process, although sometimes with several nasty side effects of the therapeutical drugs used [3, 4]. The suggestions of clinical and laboratory evidences that a small number of HIV-1 infected persons could be able to naturally control the virus without the use of anti-retroviral therapy, opened a window of hope to millions of persons carrying the enormous burden of a deadly infection [5-7].

A new phenotype of HIV-1 carriers, the long term non-progressor, elite controller or viral controller, among others, define a group of HIV-1 infected persons 
who could naturally maintain viral replication under control and the absence of precipitating events which could lead to AIDS [8-11]. The definition of viral controller and, particularly, elite controller, is not equally defined and there is no universal consensus as can be seen in the several different proposals [10, 12-14]. The suggestion of the possibility of HIV-1 eradication or the maintenance of a host who would be non infectious, is a bold proposal considering the retrospective and accumulated knowledge in virus strategies of replication, adaptation to the host and perpetuation together with the infected host [15-17].

There was a recent change in the time to start treatment of infected persons as soon as the infection is diagnosed which was also adopted in Brazil [18]. The recent evidences of three large and well conducted studies (HPTN 052, Temprano and START), were sufficiently strong to support the change, once more, in the usual protocol which define the starting point to treatment [19-21]. The "test and treat" approach may lead to a difficulty to recognize those patients who are able to maintain the virus under natural control and make it impossible to learn how the process can be attained. Here we present the characterization of the human model currently described in the city of Belem, Para (Northern Brazil), in order to provide additional criteria to turn the definition of this controversial point of discussion even more strict and to start collaborative studies in the country, aiming to better understand this phenotype of viral controllers. It is important to tighten the characterization of the subjects in order to make sure we can really believe in the control and a possible future cure of HIV-1 infection.

\section{Methods}

\section{Criteria to define the groups involved}

The classification criteria for the viremia control 1 and 2 (VC1 and VC2), and the non-viral controller (NC) groups, used information related to the number of years of known diagnosis, LTCD $4^{+}$and $\mathrm{LTCD}^{+}$counts and plasma viral load quantification are described in Table 1. It is important to emphasize that all persons were aware of their status of HIV-1 carriers for 6 years or more and were clinically and laboratory followed with their measurements of $\mathrm{LTCD}^{+}, \mathrm{LTCD}^{+}$and plasma viral load at least twice a year. All of the three groups were treatment naive and the start of ART at any time during the period of observation was the only exclusion criteria. The initial $\mathrm{LTCD}^{+}, \mathrm{LTCD}^{+}$counts and their rate were considered to be the baseline values; the latest was the last value recorded during the period of observation (from January 2007 to December 2013).

A cohort of 30 persons was distributed in three groups, VC1 $(n=2), \operatorname{VC} 2(n=7)$ and $\mathrm{NC}(n=21)$. To each person investigated, there was a group of seven to nine uninfected match controls, regarding sex and age (range of 5 years up or down) of regular blood donors from the Fundacao HEMOPA. To the VC1 there were 19 persons (nine women and ten men), to $\mathrm{VC} 2,55$ (20 women and 35 men) and NC, 167 (91 women and 76 men) controls. The composition of the cohort according to sex and age is described in Table 2.

\section{Routine examination}

The groups were routinely examined by a clinician according to the Brazilian national follow up program of HIV-1 infected persons in which they have included two to three annual measurements of HIV-1 plasma viral load and LTCD $4^{+} / \mathrm{LTCD}^{+}$counts. Viral load was initially measured using branched DNA methodology (bDNA - Bayer Corporation, Massachusetts, USA) and presently uses a Real Time PCR methodology (Abbott Molecular, USA); in both the limit of detection was 50 copies $/ \mathrm{mL}$. Lymphocyte measurements were performed using flow citometry (Becton-Dickson, USA). Both methods followed the manufacturer's recommendation.

\section{Polymorphisms of CCR5 $\Delta 32$ and SDF1-3'A}

Genomic DNA was purified from peripheral blood cells using a commercial kit (QIAamp DNA Mini Kit, QIAGEN, Germany). The genotypes of CCR $5 \triangle 32$ and SDF1-3'A were determined as previously described [22,23]. Forward and reverse primers were: F-5'GTCTTCATTACACCTGCAGC TCT-3' and R-5'-CACAGCCCTGTGCCTCTT-3' for CC R5 $\triangle 32$, F-5'CAGTCAACCTGGGCAAAGCC-3' and R-3' AGCTTTGGTCCTGAGAGTCC-5 for SDF1-3'A.

The amplification of the wild type allele of CCR5 yields a product of $189 \mathrm{bp}$, while the mutant allele (CCR5 $\Delta 32)$ yields a shorter one (157 bp). Amplification products of SDF1-3' (302 bp) were digested with restriction endonuclease MspI $5 \mathrm{U}$ (New England Biolabs), for 3 hours at $37{ }^{\circ} \mathrm{C}$. In the presence of allele 3 'A the product is not cleaved resulting in a fragment of $302 \mathrm{bp}$, but in the absence of the mutation, the fragment is cleaved in two pieces (202 and $100 \mathrm{bp}$ ). The amplified and digested products were seen following electrophoresis (100 V/45 min) in a 3\% agarose gel with Sybr Safe, diluted in TAE 1×, using a transilluminator with an ultraviolet light.

\section{Cytokine measurements}

Plasma levels of eight cytokines (IL-2, IL-4, IL-5, IL-9, IL-10, IL-13, IL-17 and IFN- $\gamma$ ) were measured using Luminex $^{\circ} \mathrm{xMAP}^{\circ}$ in a multiplex assay (Th1/Th2/Th17 Human Magnetic 8-Plex Panel for Luminex ${ }^{\text {Tu }}$ Platform 200, Invitrogen ${ }^{\mathrm{Tx}}$, USA) according to the manufacture's recommendation and read on a Luminex plataform. 


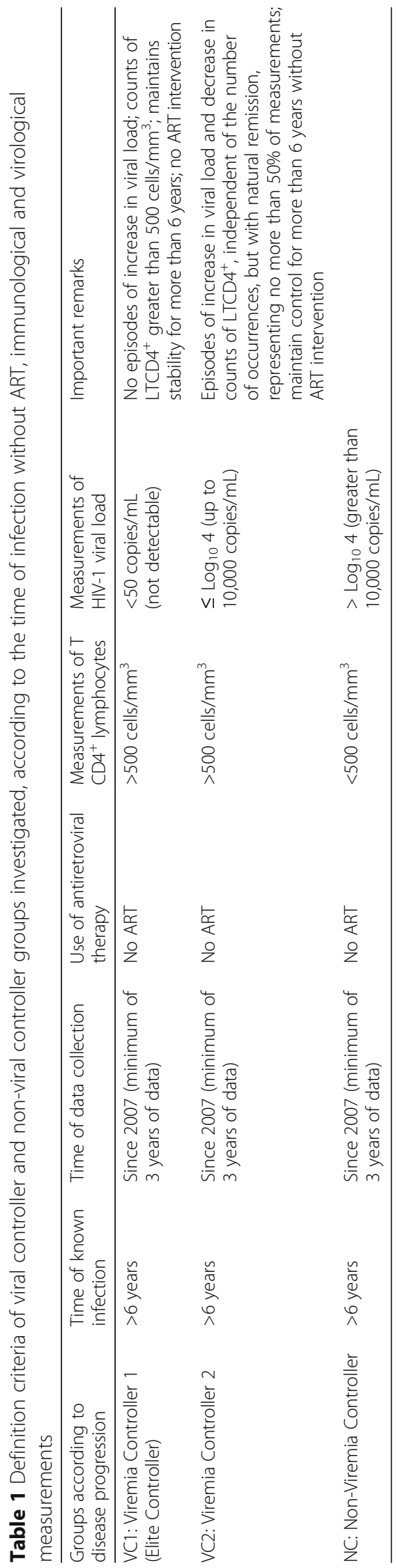


Table 2 Population composition of the three groups (viral and non-viral controllers) according to sex and age

\begin{tabular}{lllll}
\hline Groups & $\begin{array}{l}\text { Males } \\
n(\%)\end{array}$ & $\begin{array}{l}\text { Females } \\
n(\%)\end{array}$ & $\begin{array}{l}\text { Age range } \\
\text { Males }\end{array}$ & $\begin{array}{l}\text { Age range } \\
\text { Females }\end{array}$ \\
\hline VC1 & $1(50)$ & $1(50)$ & 52 & 45 \\
VC2 & $3(43)$ & $4(57)$ & $34-47$ & $35-53$ \\
NC & $11(52)$ & $10(48)$ & $28-68$ & $24-68$ \\
\hline
\end{tabular}

VC1 Viremia Controller 1 (Elite Controller), VC2 Viremia Controller 2, NC Non-Viremia Controller

\section{Statistical analysis}

Statistical analysis were performed using two softwares, GraphPad Prism, version 5.0 and BioEstat, 5.3 [24]. The association of the groups and sexual behavior was performed using the $G$ test. Construction of the Figures used median values and interquartile range. All of the available counts for each person during the period of study were used for the comparisons. The Mann-Whitney test was used to compare counts of $\mathrm{LTCD}^{+}, \mathrm{LTCD}^{+}$and their ratios among the groups involved. Significance between first and last counts of $\mathrm{LTCD}_{4}^{+}, \mathrm{LTCD}^{+}$and their ratio was performed using the Wilcoxon test. The median yearly change in absolute counts of $\mathrm{LTCD}^{+}, \mathrm{LTCD}^{+}$and their ratio was calculated by the compound annual growth rate (CAGR) as previously described [17]. The differences of CAGR between the groups were measured by the Mann-Whitney test. Chi-square and residue analysis were used to evaluate the association of plasma viral load of $\mathrm{HIV}-1$ between $\mathrm{VC}$ and $\mathrm{NC}$ groups. The polymorphisms and allele frequencies were compared using the $G$ test. The differences of cytokine levels were performed using the Mann-Whitney test. Significance was assumed at the level of 0.05 for all the statistical methods used.

\section{Results}

The age of the persons investigated in the present study, ranged from 24 to 68 years. The group included equal numbers of persons from both sexes and the majority (70\%; 21/30) referred to be single (Table 3). Most of the persons (70\%) informed to be heterosexual who make use of non-injecting drugs $(53.3 \% ; 16 / 30)$. Although they did not mention sexual relations with persons who have multiple sexual partners (93.3\%; 28/30), 46.7\% (14/30) referred to have had sexual relations with HIV-1 infected persons, $56.7 \%(16 / 30)$ do not use condoms and 51.8\% $(14 / 27)$ perform anal sex. None of the involved persons was infected either with $\mathrm{HBV}$ or $\mathrm{HCV}$. The individuals in groups $\mathrm{VC} 1$ and $\mathrm{VC} 2$, referred no promiscuity and no anal sexual relations. None of the above demographic or social characteristics showed a significant statistical level of importance.
Table 3 Demographic and social characteristics of the HIV-1 infected groups (viral controller and non-viral controller) investigated

\begin{tabular}{|c|c|c|c|c|}
\hline Variables & $\begin{array}{l}\text { VC1 } \\
n(\%)\end{array}$ & $\begin{array}{l}\text { VC2 } \\
n(\%)\end{array}$ & $\begin{array}{l}\mathrm{NC} \\
n(\%)\end{array}$ & $p$ \\
\hline \multicolumn{5}{|l|}{ Age (in years) } \\
\hline $20-40$ & 0 & $4(57)$ & $10(48)$ & \\
\hline $41-61$ & $2(100)$ & $3(43)$ & $9(43)$ & \\
\hline $62-82$ & 0 & 0 & $2(9)$ & 0.3478 \\
\hline \multicolumn{5}{|l|}{ Sex } \\
\hline Male & $1(50)$ & $3(43)$ & $11(52)$ & \\
\hline Female & $1(50)$ & $4(57)$ & $10(48)$ & 0.9089 \\
\hline \multicolumn{5}{|l|}{ Marital Status } \\
\hline Single & $1(50)$ & $4(57)$ & $16(76)$ & \\
\hline Married & $1(50)$ & $3(43)$ & $5(24)$ & 0.2460 \\
\hline \multicolumn{5}{|l|}{ Sexual behavior } \\
\hline Heterosexual & $2(100)$ & $5(72)$ & $14(67)$ & \\
\hline Homosexual & 0 & $2(28)$ & $4(19)$ & \\
\hline Bisexual & 0 & 0 & $3(14)$ & 0.4872 \\
\hline \multicolumn{5}{|l|}{ Risk Behavior } \\
\hline Use of non injecting drugs & $1(50)$ & $4(57)$ & $11(52)$ & \\
\hline Use of injecting drugs & 0 & 0 & $1(5)$ & \\
\hline No use of drugs & $1(50)$ & $3(43)$ & $9(43)$ & 0.9436 \\
\hline $\begin{array}{l}\text { Sexual relation with } \\
\text { promiscuous partner }\end{array}$ & 0 & 0 & $2(9)$ & \\
\hline $\begin{array}{l}\text { No relation with promiscuous } \\
\text { partner }\end{array}$ & $2(100)$ & $7(100)$ & $19(91)$ & 0.8259 \\
\hline $\begin{array}{l}\text { Sexual relation with } \mathrm{HIV}^{+} / \mathrm{AIDS} \\
\text { partner }\end{array}$ & $2(100)$ & $3(43)$ & $9(43)$ & \\
\hline $\begin{array}{l}\text { No sexual relation with } \mathrm{HIV}^{+} \text {/AIDS } \\
\text { partner }\end{array}$ & 0 & $4(57)$ & $12(57)$ & 0.7073 \\
\hline Use of condom & $1(50)$ & $2(29)$ & $10(48)$ & \\
\hline No use of condom ${ }^{a}$ & $1(50)$ & $5(72)$ & $11(52)$ & 0.9305 \\
\hline Anal sexual relation & 0 & $3(43)$ & $11(61)$ & \\
\hline No anal sexual relation ${ }^{\mathrm{b}}$ & $2(100)$ & $4(57)$ & $7(39)$ & 0.7347 \\
\hline
\end{tabular}

VC1 viremia controller 1 (Elite Controller), VC2 viremia controller 2, NC non-viremia controller

ancludes the answers "No" and "Sometimes"

bExcludes those who refused to answer

Viral controllers (VC1 and VC2) presented a significantly higher count of median values of LTCD4 ${ }^{+}(839$ and 673 , respectively) in comparison to the $\mathrm{NC}(370$; $p<0.0001)$, although they were still significantly lower ( $p=0.0350$ and $p<0.0001)$ when compared to their individual uninfected controls (1166, 1114 and 1110, respectively; Fig. 1a and b). $\mathrm{LTCD}^{+}$values were slightly higher among VC1 (1014), but not significantly different from the other groups (903 and 915.5); the three groups were significantly higher $(p=0.0034, p=0.0007$ and $p=0.0001)$ than their uninfected controls $(660,674$, and 660 , respectively; Fig. $1 \mathrm{c}$ and d). $\mathrm{LTCD}^{+} / \mathrm{LTCD}^{+}$ratio 


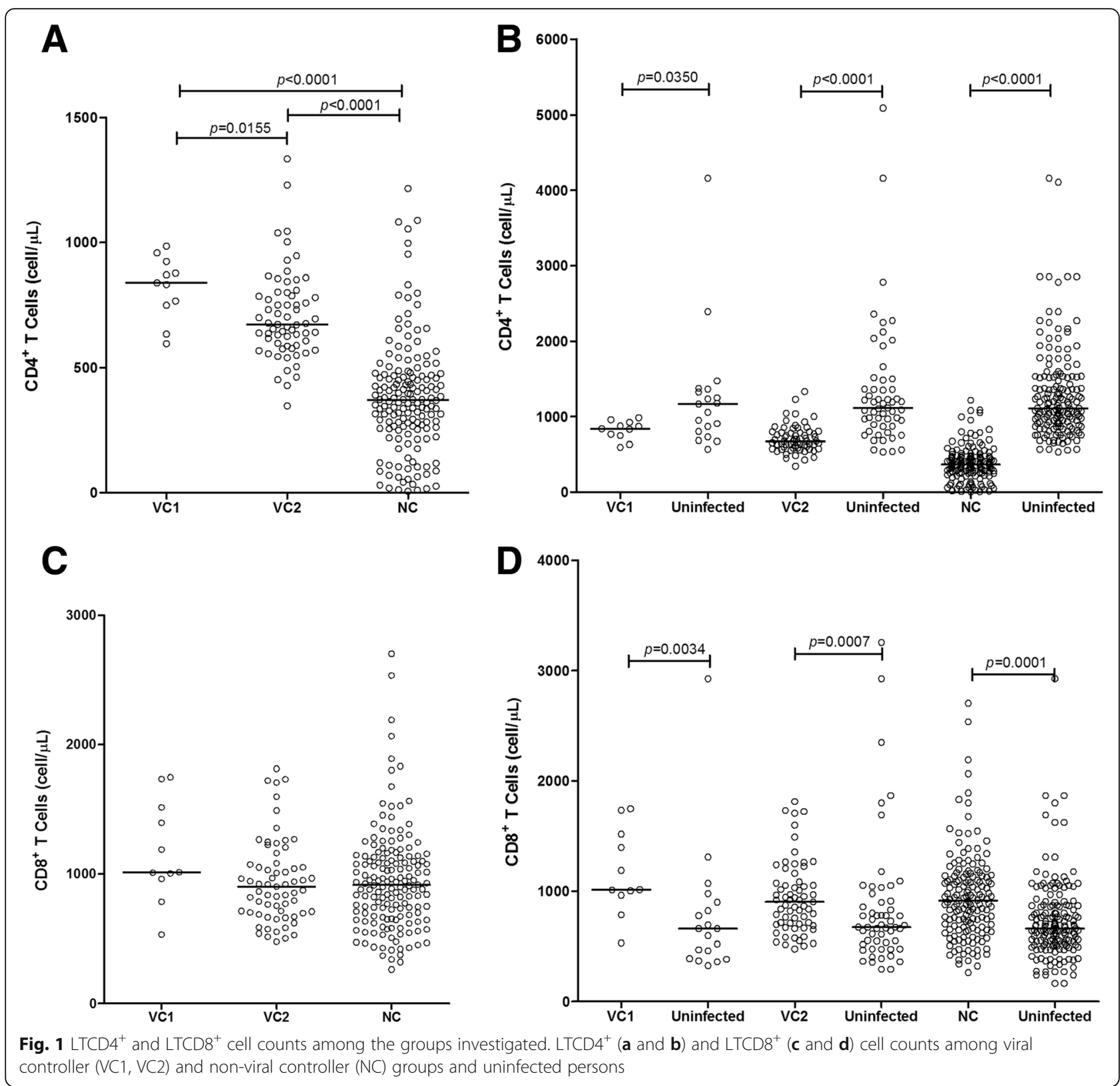

was significantly higher $(p<0.0001)$ in the VC1 $(0.73)$ and VC2 (0.82) groups as compared to the NC (0.42), but all three were significantly lower $(p<0.0001)$ than the uninfected controls (1.83, 1.64 and 1.76; Fig. 2a and b).

The evolution of $\mathrm{LTCD}^{+}$and LTCD ${ }^{+}$counts since their first laboratory examination until the end of the period of examination, showed a slight increase (without statistical significance) of LTCD4 ${ }^{+}$among the VC, but a significant $(p=0.0028)$ decrease of the NC (Fig. 3a). The percentage of annual change in $\mathrm{LTCD} 4^{+}$was also significantly different between the two groups (Fig. 3c). No difference was observed measuring $\mathrm{LTCD}^{+}$counts or estimating their annual change (Fig. 3b and d). LTCD4 ${ }^{+} / \mathrm{LTCD}^{+}{ }^{+}$ratio decreased with time. The inversion of the ratio was not significant among the $\mathrm{VC}$, but significant among the $\mathrm{NC}$, despite there was no significance of their annual change in either group (Fig. 4a and b).

HIV-1 plasma viral load of VC1 was consistently below the limit of the tests used for detection of viral nucleic acid along the observation period. Table 4 shows the frequency distribution of $\mathrm{CV}$ (CV1 and CV2) and $\mathrm{NC}$ according to four categories, ranging from undetectable to values greater than $\log _{10} 3$ (>10,000 copies/mL). The frequency of undetectable values and of those with lower counts (up to $\log _{10} 2$ ) were significantly different between the two groups ( $p$ values $>1.96$, indicating that there is a lower number of persons than expected); the frequency of higher viral loads were significantly 


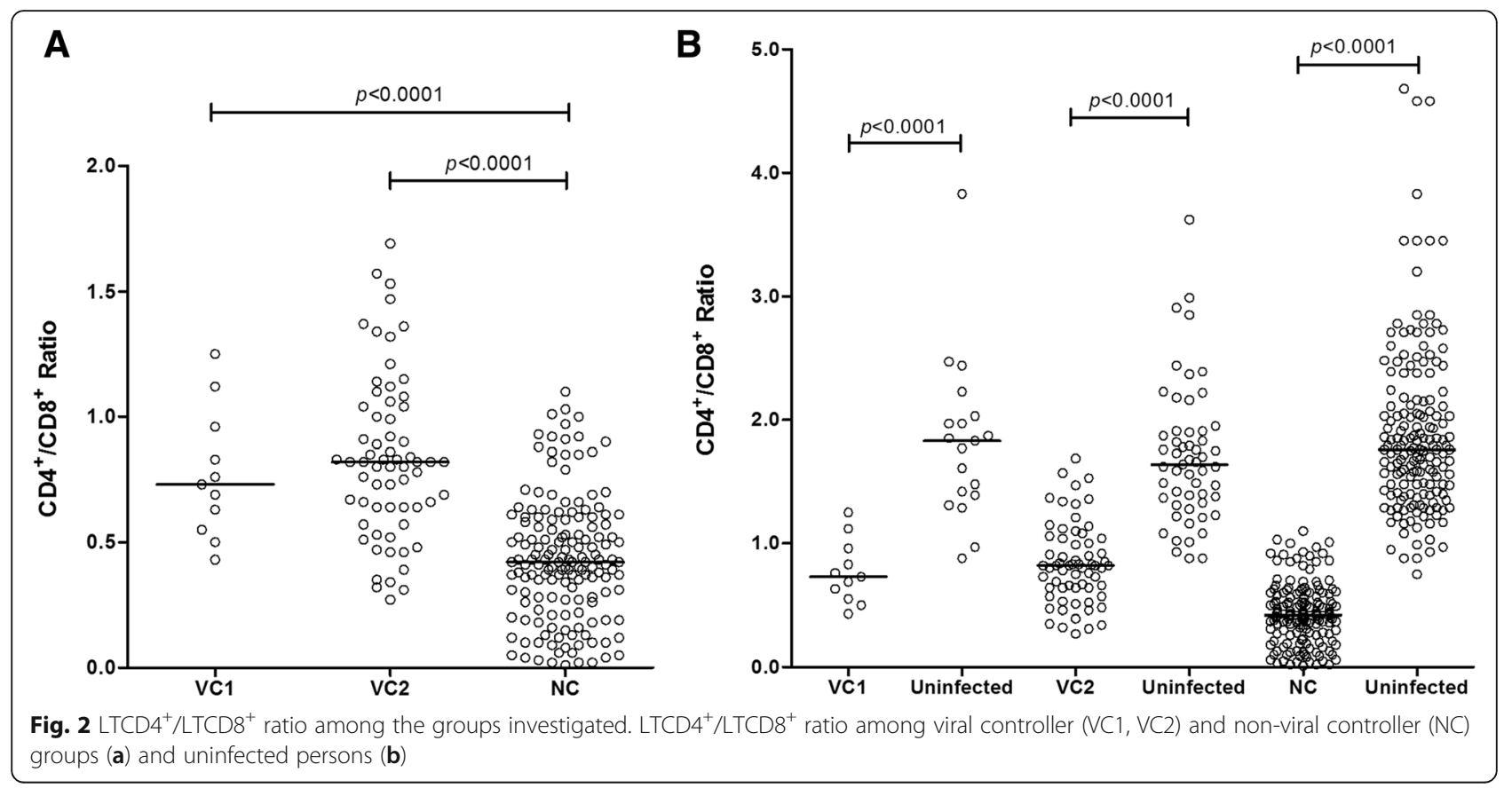

different ( $p$ values $<1.96$, indicating that there is a higher number of persons than expected) among the NC group, as measured by the residue analysis.

None of the individuals presented the CCR $5 \Delta 32^{-}$allele in homozygosis, but it was present in heterozygosis in one individual of the NC group (Table 5). SDF1-3'A polymorphisms were present in hetero and homozygosis among the three groups. No statistical significance was observed either when comparing genotypes or allele frequencies of the three groups. LTCD $4^{+}$and LTCD $8^{+}$ counts were compared according to the CCR $5 \Delta 32^{-}$and SDF1-3'A polymorphisms. Wild type alleles (Fig. 5a and c)
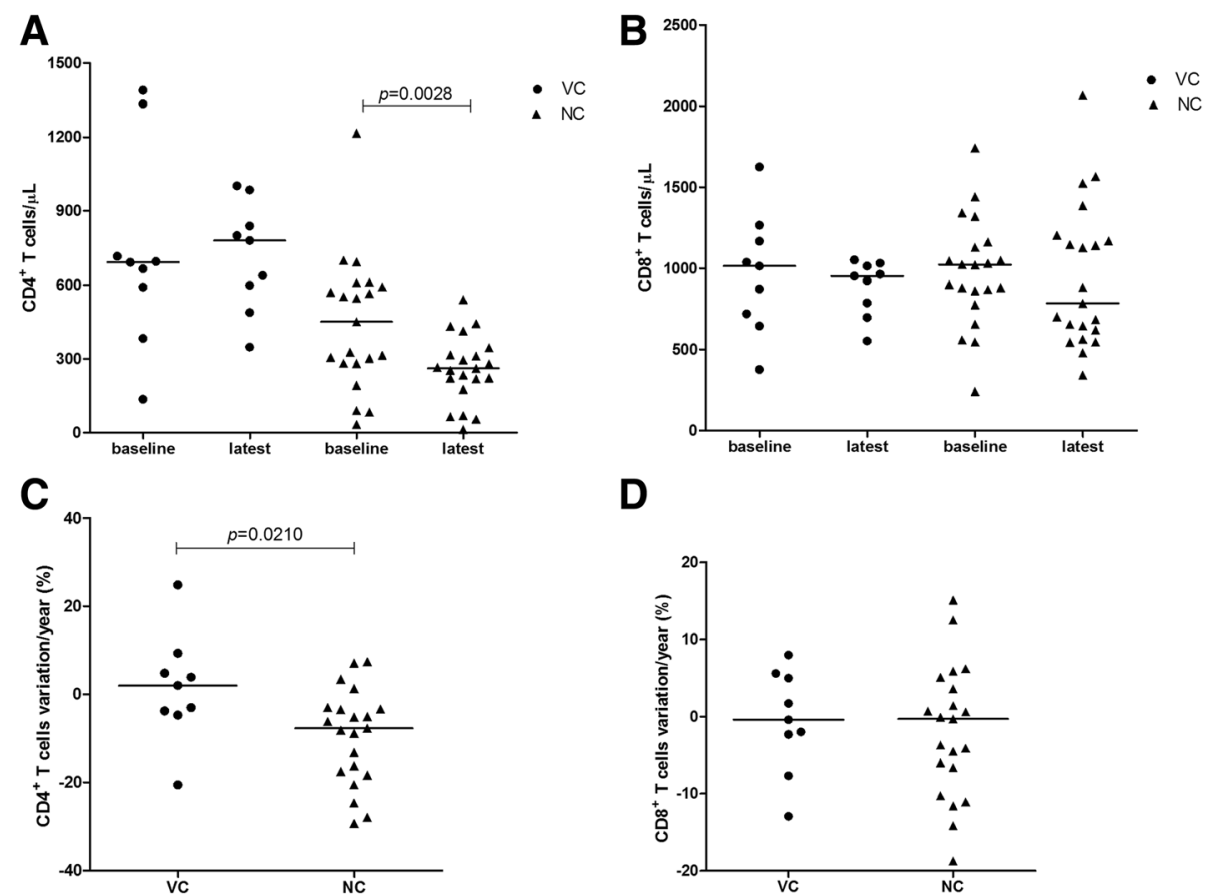

D

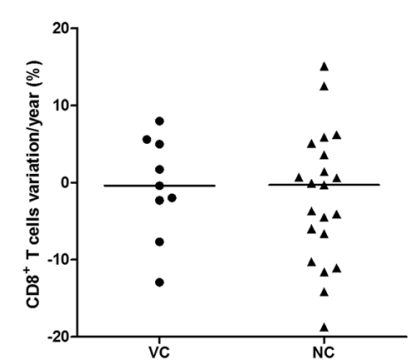

Fig. 3 Evolution of LTCD4 ${ }^{+}$and $L T C D 8^{+}$cell counts among viral controller and non-viral controller groups. Evolution of LTCD4 ${ }^{+}$and LTCD $8^{+}$cell counts among viral controller (VC1 and VC2) and non-viral controller (NC) groups; (a and b) absolute values; (c and $\mathbf{d}$ ) annual changes (in \%) in the absolute counts, measured by the CAGR 


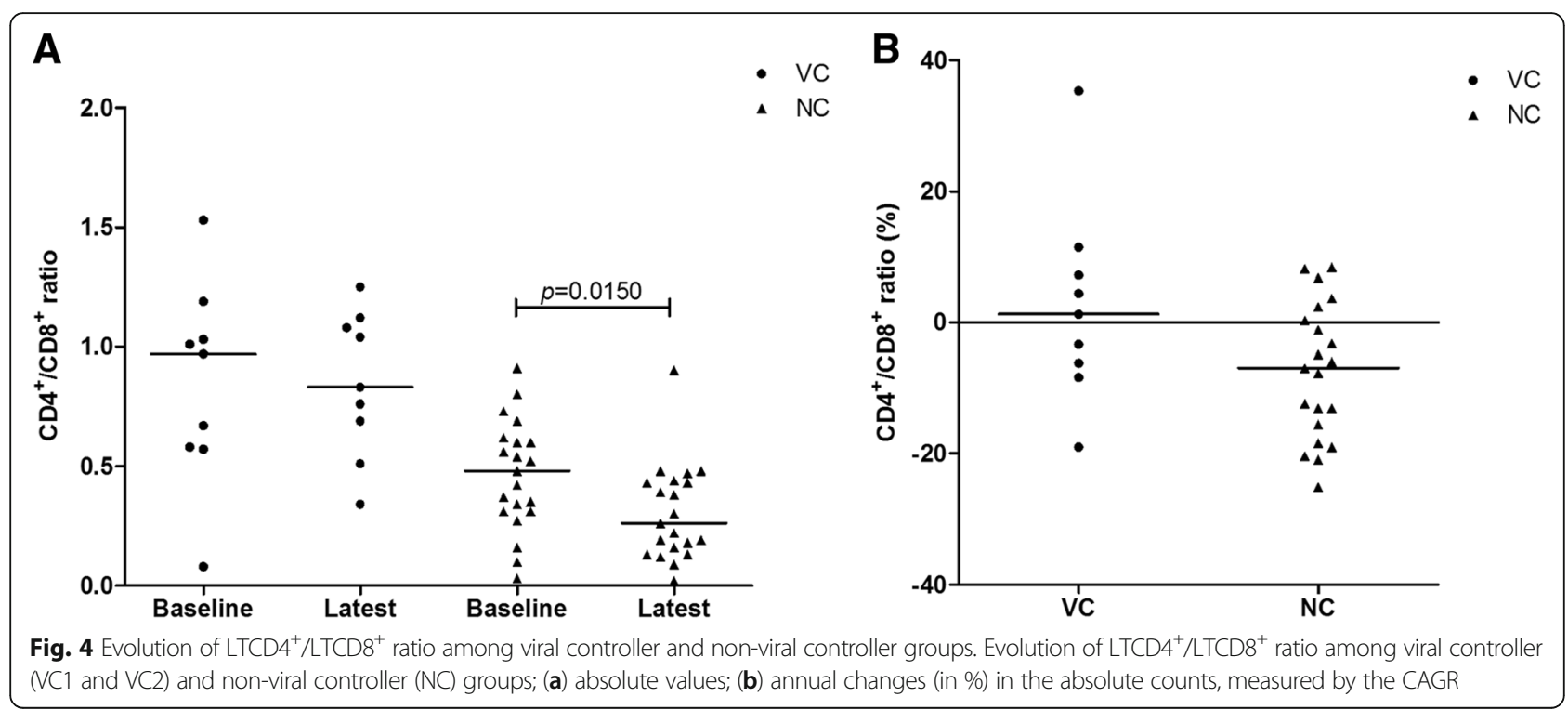

showed median values of $\mathrm{LTCD} 4^{+}>500$ lymphocytes $/ \mu \mathrm{L}$ up to 6 years after the initial diagnosis of infection, but in the presence of the allele 3'A the values were consistently lower, during the period of observation; in $36 \%$ of the measurements, they were $<350$ lymphocytes $/ \mu \mathrm{L}$. LTCD $8^{+}$ median counts (Fig. 5b and d) were consistently $<1000$ lymphocytes $/ \mu \mathrm{L}$ along the years and no significant difference was observed, despite the presence of either allele; it is relevant to mention that counts $<600$ lymphocytes $/ \mu \mathrm{L}$, were more commonly seen (24\%) among those with the 3'A allele than among those with the wild type (8\%).

Plasma levels of cytokines IFN- $\gamma$, IL-2, IL-4, IL-5, IL9, IL-10, IL-13 and IL-17, showed that IFN- $\gamma$ was significantly higher $(p=0.0482)$ in the VC group (Fig. 6a). All the others were higher in the NC group, although only IL- 4 was significantly different $(p=0.0362)$. The comparison of Th1 (IFN- $\gamma$ e IL-2) and Th2 (IL-4, IL-5, IL-10, IL-13) cytokines between the two groups (Fig. 6b and C), showed that IL-2 was present in low concentrations in both groups. However, among the NC, there

Table 4 Frequency of plasma viral load according to the HIV-1 infected groups (viral controller and non-viral controller) investigated

\begin{tabular}{lllllc}
\hline Viral load & VC $(1+2)$ & $\%$ & NC & $\%$ & $x^{2}(p)$ \\
\hline$<50$ & $13(+)$ & 22 & $8(-)$ & 5 & 57.01 \\
$51-1000$ & $19(+)$ & 32 & $14(-)$ & 10 & $(<0.0001)$ \\
$1001-10,000$ & $28(+)$ & 46 & $45(-)$ & 32 & \\
$>10,000$ & $0(-)$ & 0.0 & $75(+)$ & 53 & \\
Total & 60 & 100 & 142 & 100 &
\end{tabular}

Residue analysis (for significance level, values should be $>1.96$ or $<-1.96$; alpha level 0.05$) ;(+)$ significant positive association; (-) significant negative association; $\mathrm{VC}(1+2)$ : viremia controller 1 and viremia controller 2 NC non-viremia controller was a clear statistical significance of Th1 and Th2 cytokine profiles, with a higher concentration of Th2.

\section{Discussion}

Since the 1990s, a new group of HIV-1 infected persons was detected and they raised new possibilities regarding the outcome of an infection, which was thought to be always fatal [25]. Viremia controllers were initially seen as the natural result of the evolution of host/agent interaction, although a few decades have elapsed since the recognition of the virus and its severe consequences to the human host [23]. Virus evolution and host genetic selection would fit the idea that a new human specific group could control the virus replication without disease development. Understanding the host behavior, the

Table 5 Frequency distribution of genotype and allele frequencies of CCR5 $\triangle 32$ and SDF1-3'A polymorphisms

\begin{tabular}{lllll}
\hline Genetic profile & VC1 & VC2 & NC & $p$ \\
& $n(\%)$ & $n(\%)$ & $n(\%)$ & \\
\hline CCR5 $\Delta 32$ variant & & & & \\
CCR5 $\Delta 32+/+$ (Wild type) & $2(100)$ & $7(100)$ & $20(95)$ & \\
CCR5 $\Delta 32-/+$ (Heterozygosis) & 0 & 0 & $1(5)$ & \\
CCR5 $\Delta 32-/$ - (Mutant) & 0 & 0 & 0 & 0.9478 \\
${ }^{*}$ CCR5 $\Delta 32+$ & $4(100)$ & $14(100)$ & $40(95)$ & \\
${ }^{*}$ CCR5 $\Delta 32-$ & 0 & 0 & $2(5)$ & 0.8344 \\
SDF-1-3'A variant & & & & \\
G/G (Wild type) & $1(50)$ & $6(86)$ & $9(43)$ & \\
G/A (Heterozygosis) & 0 & $1(14)$ & $11(52)$ & \\
A/A (Mutant) & $1(50)$ & 0 & $1(5)$ & 0.1817 \\
*G & $2(50)$ & $12(86)$ & $29(69)$ & \\
${ }^{* A}$ & $2(50)$ & $2(14)$ & $13(31)$ & 0.6396 \\
\hline
\end{tabular}

"refers to the alleles

VC1 viremia controller 1, VC2 viremia controller 2, NC non-viremia controller 


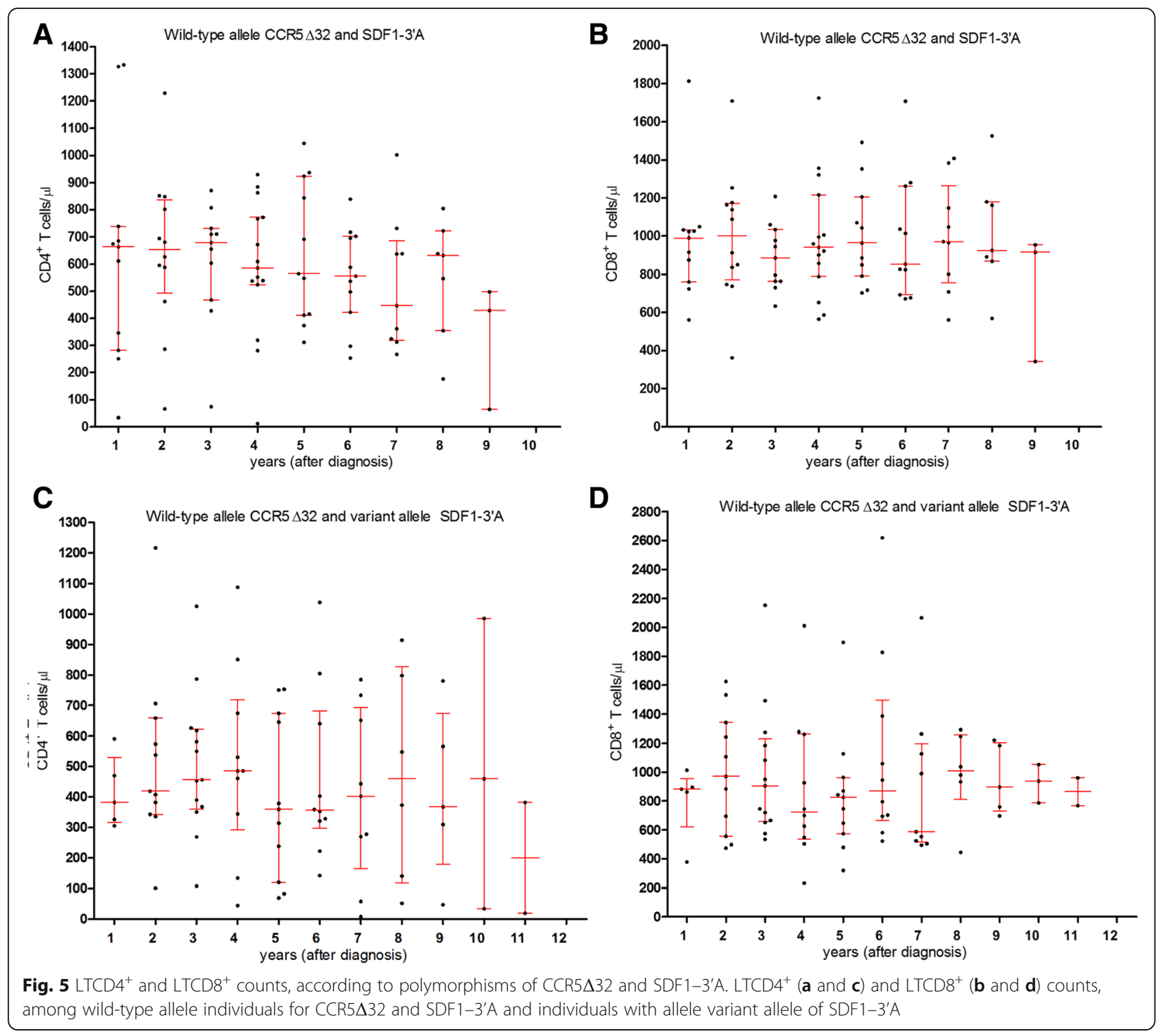

immunological response, genetic characteristics and virus pathogenesis, would certainly help understand how to improve the outcome of newly infected persons and possibly vaccine production $[26,27]$.

The present information is the first approach to characterize viral controllers in the North of the Amazon region and similar publications in the country are sparse. Demographic informations from the persons investigated were not relevant for their characterization as they were not different from the persons involved in the general epidemic of HIV-1 and AIDS elsewhere in the country. Similar results have been observed in other geographical settings regarding the demographics of viral controllers without statistical significance [28]. The importance of the similarity of the data is of relevance as the population group investigated, is highly miscigenetic [29], contrary to other groups.
The number of HIV-1 viral replication controllers is extremely low anywhere and their detection is a difficult task during the routine clinical approach. The use of statistical methods commonly used in epidemiology when dealing with rare events, was a strong statistical support, which corrected and balanced the low numbers of persons by using all the available measurements of $\mathrm{TCD}^{+}, \mathrm{TCD}^{+}$and $\mathrm{VL}$, along the observation period, and improved the statistical analysis of the numbers presented. VC1 did not show any detectable level of viral multiplication, but VC2 showed blips measured by the plasma viral load (in agreement with their definition in Table 1), which were controlled without the use of ART. It was remarkable to see that the group was able to recover from viral loads up to 10,000 copies, but this is not quite different from definitions [30] which include a limit of 2000 copies $\left(\log _{10}=3,3010\right)$. The peak of higher 


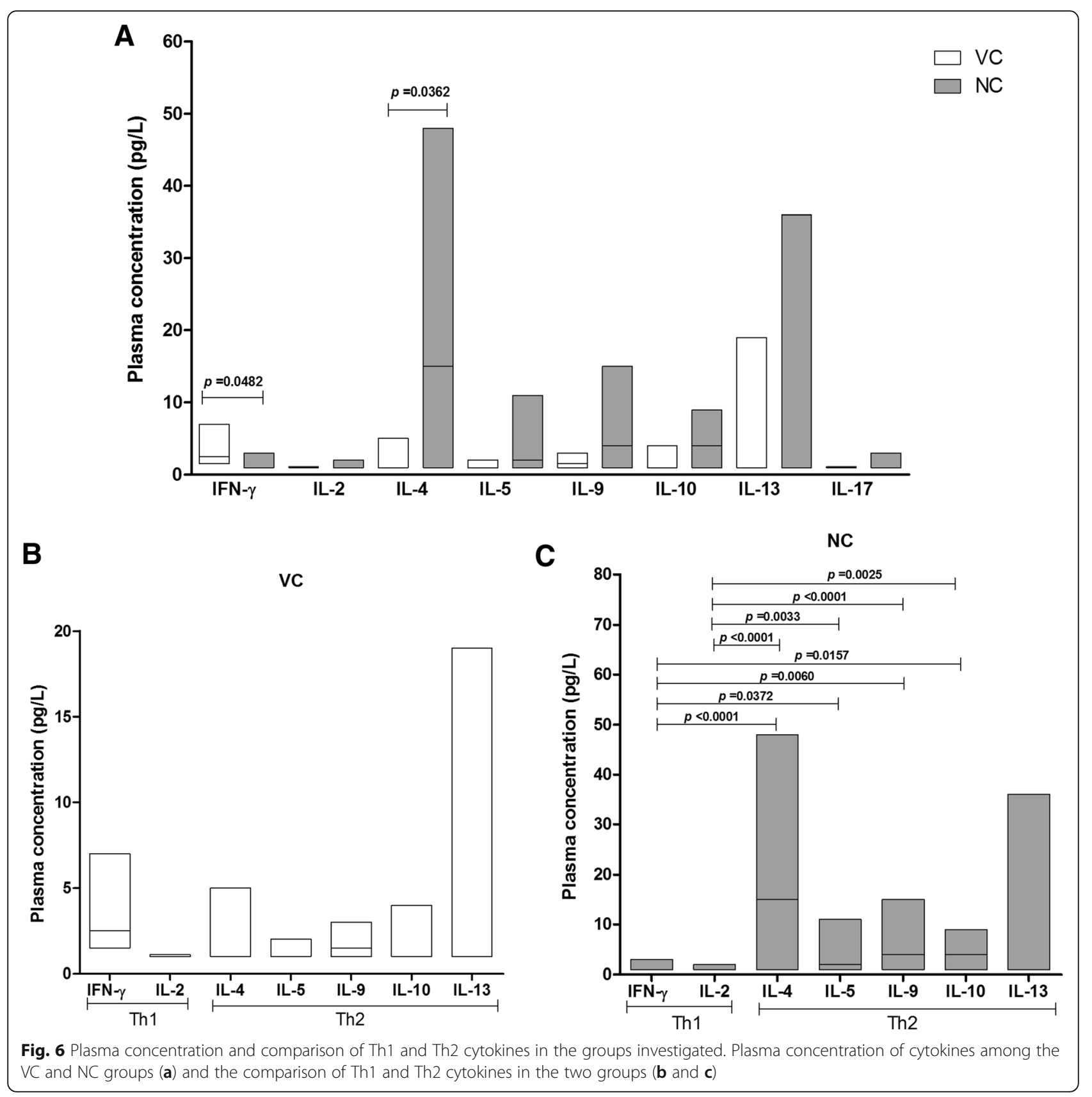

viral loads was more frequently seen in $\mathrm{NC}$ as expected. The persistence of the virus in the lymphatics acts as a constant repository for the virus from these reservoir tissues [31]. It is quite certain that the virus is in continuous replication, even among $\mathrm{VC} 1$ [16, 17, 32, 33] and it would certainly cause a decline in LTCD $4^{+}$, which was not seen in our VC groups. Cure agendas can not ignore that the groups are different and should be addressed differently in the present suggestions for "test and treat". The main point of interest is of how long should one go on waiting to consider a person as a viral controller? This is a controversial point [14] and should be addressed with priority.

Levels of $\mathrm{LTCD}^{+}$were consistently high, along the observation period among the viral controllers and the evolution of the counts showed no decrease, contrary to what has been described [17]. Absolute and relative counts of LTCD4 ${ }^{+}$, were commonly used as predictors of disease progression and the recovery of cell counts after ART, a highly relevant variable to monitor the clinical outcome of HIV-1 infected persons [34-37]. The overall annual change in their values along the observation period 
was not significant, although it was not possible to measure whether the lymphocytes were fully functional or abnormally activated. They should still be useful markers even in the present protocol of ART.

LTCD $^{+}$counts were also kept higher and did not change their levels during the observation period in the $\mathrm{VC}$ and $\mathrm{NC}$ groups. They were constantly stimulated which led to values quite higher than the uninfected controls and did not change along the years. It is still not completely understood the interaction of $\mathrm{LTCD}^{+}$in the pathogenesis of HIV-1, thus it is fair to think in the increase of the immunological response based in LTCD8 ${ }^{+}$, both to protect and to change the outcome of the disease [38-40]. A recent report showed that HIV suppressive activity mediated by $\mathrm{CD} 8^{+} \mathrm{T}$ lymphocytes in vitro was significantly greater among $\mathrm{VC}$ than $\mathrm{NC}$ cells, with a significant correlation between the suppressive activity and the plasma viral load [41]. It is a regular activity of LTCD8 ${ }^{+}$to keep adequate levels of IFN- $\gamma$, an important cytokine in the arrest of viral multiplication, both during the innate immunological response (by natural killer $\mathrm{T}$ cells) and by LTCD $8^{+}$cytotoxic cells $[8,15,42,43]$.

"Non-AIDS related events", involving chronic disorders of the CNS, the cardiovascular system and cancers are frequently described [44, 45]. Atherosclerosis and coronary heart disease, are commonly observed in an earlier age among HIV-1 carriers and no relevant clinical signs are readily detected by the patient or the attending physician. The inversion of $\mathrm{LTCD}^{+} / \mathrm{LTCD}^{+}$ratio values, is in direct association with the progress towards AIDS and non-AIDS related events and when the inversion is sharp (below 0.5), this simple measurable variable becomes a good biomarker of mortality by other causes than AIDS [46-48] and an apparently reliable marker to trace early heart disease among infected persons virally suppressed under ART [49]. Our results showed that the groups have a clear inversion of the ratio, although in a more subtle level among the viral controllers (VC1 and $\mathrm{VC} 2$ ). The marker did not change with time and the general health of the persons was apparently good. If there is a possibility of using the ratio as a biomarker, it will certainly require the definition of a cut off to establish an appropriate moment to start looking for other chronic disorders among non-controllers and the adequate moment to intervene with viral controllers as well. Apparently, there is no other published similar result considering the long term decline of LTCD4 ${ }^{+} / \mathrm{LTCD}^{+}$ratio among viral controllers, but for the period of observation in the present study, the decrease in the inversion of the ratio was not enough to be significant in the $\mathrm{VC}$ group.

The presence of CCR5 $\triangle 32$ and SDF1-3'A polymorphisms could not be associated to a better response against virus multiplication and control by the host, but the number of persons involved in the present study clearly did not allow an appropriate statistical evaluation. Our previous data showed that these polymorphisms are not usual among HIV-1 infected persons in the North region of the country [50]. Although some polymorphisms are strongly associated with viral controllers, HLA subtypes were also not associated with differences in the cytokines and chemokines production between elite controllers and viremic controllers regarding the frequencies of the alleles B27 or B57 [17, 33], contrary to what is generally accepted $[26,51-54]$. In the present study, the evolution in the counts of LTCD4 $^{+}$and LTCD8 $^{+}$were not influenced by both polymorphisms. Larger studies will be necessary to confirm or not the influence of the allele 3'A in the low counts of LTCD4 $4^{+}$ and $\mathrm{LTCD}^{+}$. Despite the absence of statistical significance there is an indication for the possible involvement of $\mathrm{M}$ tropic, using CCR5 related co-receptors and T-tropic isolates, using CXCR4 $[55,56]$. Most of these studies with polymorphisms were performed using samples from nonviral controllers with a regular progression to AIDS; viral controllers are still poorly understood regarding these and other polymorphisms.

IFN- $\gamma$ was the sole cytokine presenting a higher level in the $\mathrm{VC}$ group. The relevance of IFN- $\gamma$ resides in its ability to inhibit viral replication. The maintenance of regular levels of this cytokine is a possible consequence of LTCD8 ${ }^{+}$ activity. These cells have an important role in the expression of IFN- $\gamma$ both in the innate immunological response (by natural killer $\mathrm{T}$ cells) and by $\mathrm{CD}^{+}$cytotoxic $\mathrm{T}$ lymphocytes once antigen-specific immunity develops $[8,42]$. IFN- $\gamma$ is also an inducer of inflammatory chemokines (MIG and IP-10) which are responsible for the recruitment of leucocytes to the inflammation site and act in the chronic immune activation [56-58]. Comparisons have been drawn among different groups. The chemokines were described in lower levels among elite controllers (named $\mathrm{VC} 1$ in the present study) in comparison to other groups capable of viral replication control without ART (named as VC2 group), HIV-1 negative volunteers and HIV-1 persons under ART, but it was coherently raised among those regular progressors [10, 12, 17]. It was not possible to show in our work 7or in any other, the extension of the inflammatory response, and considering the low levels, IFN- $\gamma$ is probably more involved with control of viral replication, as we are dealing with a persistent and active viral infection. Most of the time it is shown that LTCD $8^{+}$producing IFN$\gamma$ are weak responders among the $\mathrm{VC}$ and their levels of production gradually increases among regular progressors under ART [31, 53, 59]. Inflammation markers are a common finding $[60,61]$ in the cases of treatment interruptions and the objectives of ART with the new protocol intend to suppress virus multiplication, prevent inflammation and provide an effective immune response. 
Th1 and Th2 cytokine profile between the VC and NC groups, made it possible to observe the higher plasma concentration of Th2 cytokines in the NC group and Th1 cytokines in the VC. The immune response centered in Th1 cytokines reflects a non-progressive HIV-1 disease, but it may indicate a probable helper protection against HIV-1 infection promoting phagocytosis, stimulating NK cells, $\mathrm{T}$ lymphocytes and a consequent elimination of the virus, suggesting a low grade inflammation, persistence and low level viral replication. The exacerbation of Th2 cytokine profile leading to an increased humoral response, is not sufficient for the containment of intracellular infectious agents, contributing to viral multiplication and a faster progression to AIDS [62-64]. The down regulatory effect of IL-10 on Th1 cytokines was not evident among VC; indeed, the shift observed here from Th1 to Th2 cytokines is related to progression of HIV-1 disease. IgG antibody response to HIV-1 gradually increases from viral controllers to non-viral controllers [33, 39, 65-67] which is in clear agreement with this Th1 to Th2 signature change presented here. Our results point to a distinct hypothesis proposed [17, 68] who associate the AIDS progression to the continuous inflammatory environment. It is possible to suggest that an equilibrium of the cytokine Th1 synthesis, especially the IFN-y, could be more favorable to the $\mathrm{VC}$ regarding the activation of the cellular immune response, an important step against to impair viral replication.

Numerous comparisons have been drawn among the different groups, including elite controllers, viremia controllers, HIV-1 progressors (successfully being treated or not) and HIV-1 negative volunteers [10, 12, 17], but the definition of viral controllers was not consistent in the past $[25,69,70]$ and it continues in the present. The description of this new and rare phenotype of HIV-1 infected persons, so far, has not elicited a successful characterization of the group and a large number of proposed definitions continue to impair a better understanding not only of the real prevalence numbers of the controllers, but also, of the biological mechanisms involved in the control of the virus, including those so called elite controllers [7-10, 12, 14, 71-75].

The recent suggestion for a new ART protocol [19-21], is also making us face a continuous and worrying increase in the adoption of the protocol to treat as soon as one discover his/her status of HIV-1 infection [37]. This will also soon hide all the chances to understand how the infection is modulated by the host in such a rare and special situation. Adherence to rigid criteria in the definition of viral controllers is still not attainable. The variables considered and the values taken into consideration with each of the groups, is far from a consensus. Laboratory variables, including immunological and virological ones, time of known infection, time of maintenance of virus under replicative control and decrease of host cell destruction in the absence of ART, should be more strictly followed. It is not possible to continuously face self-adequate, home made, laboratory, institution or country definitions for viral controller or elite controllers. It is relevant to mention that the conclusion of a large cohort study indicates that interruption of ART started at the early stages of infection is apparently not detrimental to treatment in the chronic phase of the disease [76].

\section{Conclusions}

The knowledge of viral controller characteristics in different population groups, including genetic background, is important to define an strict universal definition for the sake of learning about the pathogenesis of HIV-1. It is required to adhere to long periods of observation without ART, regular counts of $\mathrm{LTCD}^{+}$and $\mathrm{LTCD}^{+}$and undetected viremia. This will be the only possible way to compare such important information in order to understand the mechanisms which lead to the control of viral replication. Data on $\mathrm{LTCD}_{4}^{+}$seems to be stable and repetitive from published data, but the $\mathrm{LTCD}^{+}$response and the significance of $\mathrm{LTCD}^{+} / \mathrm{LTCD}^{+}$ratio values are in need to further exploration as biomarkers. The change from Th1 to Th2 cytokine profile may help to design and adjust specific treatment protocols for the group.

\section{Abbreviations}

ART: Antiretroviral therapy; CAGR: Compound annual growth rate; CCR5: C-C chemokine receptor type 5; CNS: Central nervous system; IFN-y: Interferongamma; IL: Interleukin; IP-10: IFN-gamma-inducible protein 10; LTCD4+: T $\mathrm{CD}^{+}$lymphocyte; $\mathrm{LTCD}^{+}$: T CD8 $8^{+}$Iymphocyte; MIG: Monokine induced by interferon-gamma; NVC: Non-viremia controllers; SDF1: Stromal cell-derived factor-1; Th: T helper cells; VC: Viremia controllers

\section{Acknowledgements}

We thank all of the individuals who participated in this research.

\section{Funding}

This study was supported by the Conselho Nacional de Desenvolvimento Científico e Tecnológico - CNPQ.

\section{Availability of data and materials}

All data generated or analysed during this study are included in this published article. The raw data belongs to the Virus Laboratory of the Federal University of Para. The data cannot be accessed without the approval of the Ethical Committee of Federal University of Para and the Brazilian Ministry of Health, as there are ethical restrictions on the data, given that the research deals with information starting from biological samples taken from patients. Interested researchers should send requests to access the data to the corresponding author at rishak@ufpa.br.

\section{Authors' contributions}

Conception and design of the study: RI, MOGI, ACRV, STMG and ERG. Analysis and interpretation of the data: RI, MOGI and ACRV. Collection and assembly of the data: Rl, MOGI, ACRV, LFAM, SSL, STMG, ERG, MAFQ, IMCV and MBS. Drafting of the article: RI, MOGI, ACRV and IMCV. Critical revision of the article for important intellectual content: RI, MOGI, ACRV, LFAM, SSL, STMG, ERG, MAFQ, IMCV and MBS. Final approval of the article: RI and ACRV. All authors read and approved the final manuscript. 


\section{Consent for publication}

Not applicable.

\section{Ethics approval and consent to participate}

The project was approved by the Ethics Committee of the Tropical Medicine Center of the Universidade Federal do Para (\#275.456). All persons were briefed about the project. All participants were adults and those who accepted to take part were asked to and signed an informed consent form.

\section{Publisher's Note}

Springer Nature remains neutral with regard to jurisdictional claims in published maps and institutional affiliations.

Received: 8 May 2017 Accepted: 24 May 2017

Published online: 01 June 2017

\section{References}

1. Pantaleo G, Fauci AS. Immunopathogenesis of HIV infection. Annu rev Microbiol. 1996;50:825-54.

2. Sáez-Cirión A, Bacchus C, Hocqueloux L, Avettand-Fenoel V, Girault I Lecuroux C, et al. Post-treatment HIV-1 controllers with a long-term virological remission after the interruption of early initiated antiretroviral therapy ANRS VISCONTI study. PLoS Pathog. 2013;9:e1003211. doi:10.1371/ journal.ppat.1003211

3. Cohen MS, Chen YQ, McCauley M, Gamble T, Hosseinipour MC, Kumarasamy N, et al. Prevention of HIV-1 infection with early antiretroviral therapy. N Engl J med. 2011;365:493-505.

4. Diaz RSD, Vásquez VS. Infecção pelo HIV e terapia antirretroviral em 2012. Brasil: Permanyer Brasil Publicações; 2012.

5. Sheppard HW, Lang W, Ascher MS, Vittinghoff E, Winkelstein W. The characterization of non-progressors: long-term HIV-1 infection with stable CD4+ T-cell levels. Aids. 1993;7:1159-66.

6. Cao Y, Qin L, Zhang L, Safrit J, Ho DD. Virologic and immunologic characterization of long-term survivors of human immunodeficiency virus type 1 infection. N Engl J med. 1995;332:201-8.

7. Deeks SG, Walker BD. Human immunodeficiency virus controllers: mechanisms of durable virus control in the absence of antiretroviral therapy. Immunity. 2007;27:406-16.

8. Lambotte O, Boufassa F, Madec Y, Nguyen A, Goujard C, Meyer L, et al. HIV controllers: a homogeneous group of HIV-1-infected patients with spontaneous control of viral replication. Clin Infect Dis. 2005;41:1053-6.

9. Pereyra F, Addo MM, Kaufmann DE, Liu Y, Miura T, Rathod A, et al. Genetic and immunologic heterogeneity among persons who control HIV infection in the absence of therapy. J Infect Dis. 2008;197:563-71.

10. Okulicz JF, Marconi VC, Landrum ML, Wegner S, Weintrob A, Ganesan A, et al. Clinical outcomes of elite controllers, viremic controllers, and longterm nonprogressors in the US Department of defense HIV natural history study. J Infect Dis. 2009;200:1714-23.

11. Saag M, Deeks SG. How do HIV elite controllers do what they do? Clin Infect Dis. 2010;51:239-41.

12. Walker BD. Elite control of HIV infection: implications for vaccines and treatment. Top HIV med. 2007;15:134-6.

13. Sajadi MM, Constantine NT, Mann DL, Charurat M, Dadzan E, Kadlecik P, et al. Epidemiologic characteristics and natural history of HIV-1 natural viral suppressors. J Acquir Immune Defic Syndr. 2009;50:403-8.

14. Olson AD, Meyer L, Prins M, Thiebaut R, Gurdasani D, Guiguet M, et al. An evaluation of HIV elite controller definitions within a large seroconverter cohort collaboration. PLoS One. 2014;9:e86719. doi:10.1371/journal.pone.0086719.

15. Espíndola MS, Soares LS, Galvão-Lima LJ, Zambuzi FA, Cacemiro MC, Brauer VS, et al. HIV infection: focus on the innate immune cells. Immunol res. 2016;64:1118-32

16. Martinez-Picado J, Deeks SG. Persistent HIV-1 replication during antiretroviral therapy. Curr Opin HIV AIDS. 2016;11:417-23.

17. Platten M, Jung N, Trapp S, Flossdorf P, Meyer-Olson D. Schulze Zur Wiesch J, et al. Cytokine and Chemokine Signature in Elite versus Viremic Controllers Infected with HIV AIDS res hum Retroviruses. 2016;32:579-87.

18. Brasil. Ministério da Saúde. Secretaria de Vigilância em Saúde. Departamento de DST, Aids e Hepatites Virais. Protocolo clínico e diretrizes terapêuticas para manejo da infecção. Ministério da Saúde, Secretaria de Vigilância em Saúde, Departamento de DST, Aids e Hepatites Virais. - Brasília : Ministério da Saúde, 2015. Available: http://www.aids.gov.br/sites/default/files/anexos/ publicacao/2013/55308/protocolofinal_31_7_2015_pdf_31327.pdf. Accessed 10 Sept 2016.

19. Grinsztejn B, Hosseinipour MC, Ribaudo HJ, Swindells S, Eron J, Chen YQ, et al. Effects of early versus delayed initiation of antiretroviral treatment on clinical outcomes of HIV-1 infection: results from the phase 3 HPTN 052 randomised controlled trial. Lancet Infect Dis. 2014;14:281-90.

20. ANRS Temprano 12136 Study Group. A trial of early antiretrovirals and isoniazid preventive therapy in Africa. N Engl J med. 2015;373:808-22.

21. Insight START Study Group. Initiation of antiretroviral therapy in early asymptomatic HIV infection. N Engl J med. 2015;373:795-807.

22. Dean M, Carrington M, Winkler C, Huttley GA, Smith MW, Allikmets R, et al. Genetic restriction of HIV-1 infection and progression to AIDS by a deletion allele of the CKR5 structural gene. Hemophilia growth and development study, Multicenter AIDS cohort study, Multicenter hemophilia cohort study, san Francisco City cohort, ALIVE study. Science. 1996;273:1856-62.

23. Winkler C, Modi W, Smith MW, Nelson GW, Wu X, Carrington M, et al. Genetic restriction of AIDS pathogenesis by an SDF-1 chemokine gene variant. ALIVE study, hemophilia growth and development study (HGDS), Multicenter AIDS cohort study (MACS), Multicenter hemophilia cohort study (MHCS), san Francisco City cohort (SFCC). Science. 1998;279:389-93.

24. Ayres M, Ayres MJ, Ayres DL, Santos AS. BioEstat 5.0: aplicações estatísticas nas áreas das ciências biológicas e médicas. 5st ed. Editora Instituto de desenvolvimento sustentável Mamirauá; Brasília IDSM/MCT/CNPq, 2007.

25. Liu SL, Schacker T, Musey L, Shriner D, McElrath MJ, Corey L, et al. Divergent patterns of progression to AIDS after infection from the same source: HIV type 1 evolution and antiviral responses. J Virol. 1997;71:4284-95.

26. Carrington M, Walker BD. Immunogenetics of spontaneous control of HIV Annu rev med. 2012;63:131-45.

27. Okulicz JF. Elite Controllers and Long-term Nonprogressors: Models for HIV Vaccine Development? J AIDS Clinic Res. 2012. doi:10.4172/2155-6113.1000139.

28. Yang OO, Cumberland WG, Escobar R, Liao D, Chew KW. Demographics and natural history of HIV-1-infected spontaneous controllers of viremia: extremes on a continuum. Aids. 2017;31:1091-8.

29. Santos SEB, Guerreiro JF. The indigenous contribution to the formation of the population of the Brazilian Amazon region. Rev Bras Genet. 1995;18:311-5.

30. Okulicz JF, Lambote $O$. Epidemiology and clinical characteristics of elite controllers. Current Opinion HIV AIDS. 2011;6:163-8.

31. Boritz EA, Darko S, Swaszek L, Wolf G, Wells D, Wu X, et al. Multiple origins of virus persistence during natural control of HIV infection. Cell. 2016;166: 1004-15.

32. Pereyra F, Palmer S, Miura T, Block BL, Wiegand A, Rothchild AC, et al. Persistent low-level viremia in HIV-1 elite controllers and relationship to immunologic parameters. J Infect Dis. 2009;200:984-90.

33. Côrtes FH, Passaes CP, Bello G, Teixeira SL, Vorsatz C, Babic D, et al. HIV controllers with different viral load cutoff levels have distinct virologic and immunologic profiles. J Acquir Immune Defic Syndr. 2015;68:377-85.

34. Moore DM, Hogg RS, Yip B, Craib K, Wood E, Montaner JS. CD4 percentage is an independent predictor of survival in patients starting antiretroviral therapy with absolute CD4 cell counts between 200 and 350 cells/microL. HIV med. 2006;7:383-8.

35. Hulgan T, Shepherd BE, Raffanti SP, Fusco JS, Beckerman R, Barkanic G, et al. Absolute count and percentage of CD4+ lymphocytes are independent predictors of disease progression in HIV-infected persons initiating highly active antiretroviral therapy. J Infect Dis. 2007;195:425-31.

36. Torti C, Prosperi M, Motta D, Digiambenedetto S, Maggiolo F, Paraninfo G, et al. Factors influencing the normalization of CD4+ T-cell count, percentage and CD4+/CD8+ T-cell ratio in HIV-infected patients on longterm suppressive antiretroviral therapy. Clin Microbiol Infect. 2012;18:449-58.

37. Eholié SP, Badje A, Kouame GM, N'takpe JB, Moh R, Danel C, et al. Antiretroviral treatment regardless of CD4 count: the universal answer to a contextual question. AIDS Res Ther. 2016. doi: 10.1186/s12981-016-0111-1.

38. Mudd PA, Martins MA, Ericsen AJ, Tully DC, Power KA, Bean AT, et al. Vaccine-induced CD8+ T cells control AIDS virus replication. Nature. 2012; 491:129-33.

39. Lécuroux C, Sáez-Cirión A, Girault I, Versmisse P, Boufassa F, Avettand-Fenoë $\checkmark$, et al. Both HLA-B*57 and plasma HIV RNA levels contribute to the HIVspecific CD8+ T cell response in HIV controllers. J Virol. 2014;88:176-87.

40. Martins MA, Tully DC, Cruz MA, Power KA, Veloso de Santana MG, Bean DJ, et al. Vaccine-induced simian immunodeficiency virus-specific CD8+ T-cell responses focused on a single nef epitope select for escape variants shortly after infection. J Virol. 2015;89:10802-20. 
41. Yada Tansiri Y, Rowland-Jones SL, Ananworanich J, Hansasuta P. Clinical outcome of HIV Viraemic controllers and Noncontrollers with normal CD4 counts is exclusively determined by antigen-specific CD8 ${ }^{+} \mathrm{T}$-cell-mediated HIV suppression. PLoS. 2015;10:e0118871. doi:10.1371/journal.pone.0118871.

42. Grabar S, Selinger-Leneman H, Abgrall S, Pialoux G, Weiss L, Costagliola D. Prevalence and comparative characteristics of long-term nonprogressors and HIV controller patients in the French hospital database on HIV. Aids. 2009;23:1163-9.

43. Kløverpris HN, Kazer SW, Mjösberg J, Mabuka JM, Wellmann A, Ndhlovu Z, et al. Innate lymphoid cells are depleted irreversibly during acute HIV-1 infection in the absence of viral suppression. Immunity. 2016:44:391-405.

44. Deeks SG, Phillips AN. HIV infection, antiretroviral treatment, ageing, and non-AIDS related morbidity. BMJ. 2009. doi: 10.1136/bmj.a3172.

45. Hsue PY, Hunt PW, Schnell A, Kalapus SC, Hoh R, Ganz P, et al. Role of viral replication, antiretroviral therapy, and immunodeficiency in HIV-associated atherosclerosis. Aids. 2009:23:1059-67.

46. Wikby A, Ferguson F, Forsey R, Thompson J, Strindhall J, Löfgren S, et al. An immune risk phenotype, cognitive impairment, and survival in very late life: impact of allostatic load in Swedish octogenarian and nonagenarian humans. J Gerontol a Biol Sci med Sci. 2005;60:556-65.

47. Hadrup SR, Strindhall J, Køllgaard T, Seremet T, Johansson B, Pawelec G, et al. Longitudinal studies of clonally expanded CD8 T cells reveal a repertoire shrinkage predicting mortality and an increased number of dysfunctional cytomegalovirus-specific T cells in the very elderly. J Immunol. 2006;176:2645-53.

48. Wikby A, Nilsson BO, Forsey R, Thompson J, Strindhall J, Löfgren S, et al. The immune risk phenotype is associated with IL- 6 in the terminal decline stage: findings from the Swedish NONA immune longitudinal study of very late life functioning. Mech Ageing dev. 2006;127:695-704.

49. Bernal Morell E, Serrano Cabeza J, Muñoz Á, Marín I, Masiá M, Gutiérrez F, et al. The CD4/CD8 ratio is inversely associated with carotid intima-media thickness progression in human immunodeficiency virus-infected patients on antiretroviral treatment. AIDS res hum Retrovir. 2016;32:648-53.

50. Carvalhaes FAPL, Cardoso GL, Vallinoto ACR, Machado LF, Ishak MOG, Ishak $R$, et al. Frequencies of CCR5 $\triangle 32$, CCR2-64I and SDF1-3'A mutations in human immunodeficiency virus (HIV) seropositive subjects and seronegative individuals from the state of Pará in Brazilian Amazonia. Genet Mol Biol. 2005;28:665-9.

51. Kaslow RA, Carrington M, Apple R, Park L, Muñoz A, Saah AJ, et al. Influence of combinations of human major histocompatibility complex genes on the course of HIV-1 infection. Nat med. 1996;2:405-11.

52. Magierowska M, Theodorou I, Debré $P$, Sanson F, Autran B, Rivière $Y$, et al. Combined genotypes of CCR5, CCR2, SDF1, and HLA genes can predict the long-term nonprogressor status in human immunodeficiency virus-1infected individuals. Blood. 1999;93:936-41.

53. Sáez-Cirión A, Sinet M, Shin SY, Urrutia A, Versmisse $P$, Lacabaratz $C$, et al. Heterogeneity in HIV suppression by CD8 T cells from HIV controllers: association with gag-specific CD8 T cell responses. J Immunol. 2009;182:7828-37.

54. Pereyra F, Jia X, McLaren PJ, Telenti A, de Bakker PI, Walker BD, et al. The major genetic determinants of HIV-1 control affect HLA class I peptide presentation. Science. 2010;330:1551-7.

55. Cocchi F, DeVico AL, Garzino-Demo A, Arya SK, Gallo RC, Lusso P. Identification of RANTES, MIP-1 alpha, and MIP-1 beta as the major HIVsuppressive factors produced by CD8+ T cells. Science. 1995;270:1811-5.

56. Feng Y, Broder CC, Kennedy PE, Berger EA. HIV-1 entry cofactor: functional cDNA cloning of a seven-transmembrane, G protein-coupled receptor. Science. 1996;272:872-7.

57. Kamat A, Misra V, Cassol E, Ancuta P, Yan Z, Li C, et al. A plasma biomarker signature of immune activation in HIV patients on antiretroviral therapy. PLoS One. 2012: e30881. doi: 10.1371/journal.pone.0030881.

58. Noel N, Boufassa F, Lécuroux C, Saez-Cirion A, Bourgeois C, Dunyach-Remy $C$, et al. Elevated IP10 levels are associated with immune activation and low CD4 $^{+}$T-cell counts in HIV controller patients. Aids. 2014;28:467-76.

59. Karlsson AC, Younger SR, Martin JN, Grossman Z, Sinclair E, Hunt PW, et al. Immunologic and virologic evolution during periods of intermittent and persistent low-level viremia. Aids. 2004;18:981-9.

60. Emery S, Neuhaus JA, Phillips AN, Babiker A, Cohen CJ, Gatell JM, et al. Major clinical outcomes in antiretroviral therapy (ART)-naive participants and in those not receiving ART at baseline in the SMART study. J Infect Dis. 2008;197:1133-44.

61. Rodger AJ, Fox Z, Lundgren JD, Kuller LH, Boesecke C, Gey D, et al. Activation and coagulation biomarkers are independent predictors of the development of opportunistic disease in patients with HIV infection. J Infect Dis. 2009;200:973-83.

62. Clerici M, Shearer GM. The Th1-Th2 hypothesis of HIV infection: new insights. Immunol Today. 1994;15:575-81.

63. Fenoglio D, Poggi A, Catellani S, Battaglia F, Ferrera A, Setti M, et al. Vdelta1 T lymphocytes producing IFN-gamma and IL-17 are expanded in HIV-1infected patients and respond to Candida albicans. Blood. 2009;113:6611-8.

64. de Medeiros RM, Valverde-Villegas JM, Junqueira DM, Gräf T, Lindenau JD, de Mello MG, et al. Rapid and slow progressors show increased IL-6 and IL10 levels in the pre-AIDS stage of HIV infection. PLoS One. 2016: e0156163. doi: 10.1371/journal.pone .0156163.

65. Hayashida T, Gatanaga H, Tanuma J, Oka S. Effects of low HIV type 1 load and antiretroviral treatment on lgG-capture BED-enzyme immunoassay. AIDS res hum Retrovir. 2008;24:495-8.

66. Bello G, Velasco-de-Castro CA, Bongertz V, Rodrigues CA, Giacoia-Gripp CB, Pilotto $\mathrm{JH}$, et al. Immune activation and antibody responses in non-progressing elite controller individuals infected with HIV-1. J med Virol. 2009;81:1681-90.

67. Wendel SK, Mullis CE, Eshleman SH, Blankson JN, Moore RD, Keruly JC, et al. Effect of natural and ARV-induced viral suppression and viral breakthrough on anti-HIV antibody proportion and avidity in patients with HIV-1 subtype B infection. PLoS One. 2013: e55525. doi: 10.1371/journal.pone.0055525.

68. Williams A, Steffens F, Reinecke C, Meyer D. The Th1/Th2/Th17 cytokine profile of HIV-infected individuals: a multivariate cytokinomics approach. Cytokine. 2013;61:521-6.

69. Pantaleo G, Menzo S, Vaccarezza M, Graziosi C, Cohen OJ, Demarest JF, et al Studies in subjects with long-term nonprogressive human immunodeficiency virus infection. N Engl J med. 1995;332:209-16.

70. Strathdee SA, Veugelers PJ, Page-Shafer KA, McNulty A, Moss AR, Schechter $M T$, et al. Lack of consistency between five definitions of nonprogression in cohorts of HIV-infected seroconverters. Aids. 1996;10:959-65.

71. Okulicz JF, Grandits GA, Weintrob AC, Landrum ML, Ganesan A, CrumCianflone NF, et al. CD4 T cell count reconstitution in HIV controllers after highly active antiretroviral therapy. Clin Infect Dis. 2010;50:1187-91.

72. Owen RE, Heitman JW, Hirschkorn DF, Lanteri MC, Biswas HH, Martin JN, et al. HIV+ elite controllers have low HIV-specific T-cell activation yet maintain strong, polyfunctional T-cell responses. Aids. 2010;24:1095-105.

73. López M, Soriano V, Peris-Pertusa A, Rallón N, Restrepo C, Benito JM. Elite controllers display higher activation on central memory CD8 T cells than HIV patients successfully on HAART. AIDS res hum Retrovir. 2011;27:157-65.

74. Sáez-Cirión A, Hamimi C, Bergamaschi A, David A, Versmisse P, Mélard A, et al. Restriction of HIV-1 replication in macrophages and CD4+ T cells from HIV controllers. Blood. 2011;118:955-64.

75. Eriksson EM, Milush JM, Ho EL, Batista MD, Holditch SJ, Keh CE, et al. Expansion of CD8+ T cells lacking Sema4D/CD100 during HIV-1 infection identifies a subset of T cells with decreased functional capacity. Blood. 2012;119:745-55.

76. Pantazis N, Touloumi G, Meyer L, Olson A, Costagliola D, Kelleher AD, et al. The impact of transient combination antiretroviral treatment in early HIV infection on viral suppression and immunological response in later treatment. Aids. 2016;30:879-88.

\section{Submit your next manuscript to BioMed Central and we will help you at every step:}

- We accept pre-submission inquiries

- Our selector tool helps you to find the most relevant journal

- We provide round the clock customer support

- Convenient online submission

- Thorough peer review

- Inclusion in PubMed and all major indexing services

- Maximum visibility for your research

Submit your manuscript at www.biomedcentral.com/submit
C Biomed Central 